\title{
SPATIAL ASSESSMENT OF BUILT-UP AND RECREATION EXPANSION USING GEO-INFORMATIC TECHNIQUE IN KOH CHANG ISLAND, THAILAND
}

\author{
Pranita JUNGPANICH \\ Suan Sunandha Rajabhat University, Faculty of Humanities and Social Sciences, \\ Geography and Geo-Informatics Program, Bangkok Thailand, e-mail: s61122401008@ssru.ac.th \\ Katawut WAIYASUSRI* \\ Suan Sunandha Rajabhat University, Faculty of Humanities and Social Sciences, \\ Geography and Geo-Informatics Program, Bangkok, Thailand, e-mail: katawut.wa@ssru.ac.th
}

\begin{abstract}
Citation: Jungpanich, P., \& Waiyasusri, K. (2021). SPATIAL ASSESSMENT OF BUILT-UP AND RECREATION EXPANSION USING GEO-INFORMATIC TECHNIQUE IN KOH CHANG ISLAND, THAILAND. GeoJournal of Tourism and Geosites, 39(4spl), 1501-1506. https://doi.org/10.30892/gtg.394spl21-794
\end{abstract}

\begin{abstract}
Land-use change for examining the expansion of built-up and recreation, required effective techniques of spatial assessment, especially in areas with limited space such as Koh Chang island in Thailand which needed to be emphasized. The research objectives were to study land-use patterns in Koh Chang area in Trat province from 2000-2020, and study land-use change, especially the expansion of buildings and recreation area during that period, using geo-informatic technique. The study found that most of Koh Chang is forest land, up to $80 \%$ of the island, but the trend is declining. On the other hand, the area that has increased in number is built-up and recreation, which has increased from $7.22 \mathrm{~km}^{2}$ to $18.28 \mathrm{~km}^{2}$ and up to $253.19 \%$ in the past 20 years. The efficiency of geo-informatic technology can extract useful information, especially spatial data on land-use change. Therefore, it is known from which areas built-up and recreation areas are transformed in order to bring such information into a spatial database system for supporting decision-making in directing, monitoring and controlling areas for further expansion of tourism business in order not to create an impact on the environment.
\end{abstract}

Key words: Spatial assessment, Built-up and Recreation Expansion, Geo-informatic, Koh Chang Island, Tourism

\section{INTRODUCTION}

Tourism is a major economic activity in the tropical region, especially in developing countries in Southeast Asia that rely on tourism revenues to drive the national economy (Gilani et al., 2015; Osman et al., 2016). Tourism activities in various forms, whether in the form of trade, service business, as well as the expansion of local infrastructure, have clearly affected the change in land-use patterns, expansion of buildings, especially in business districts, construction of buildings, residences, hotels, resorts and roads for easier and more convenient access to tourist areas has recently accommodated tourists (Dimobe et al., 2017; Gaughan et al., 2009). As a result, natural resources problems gradually deteriorated due to the expansion of such buildings and infrastructure (Indarto and Hakim, 2021). Therefore, the study of land-use patterns is necessary to create a spatial database for the management of land-use planning in urban areas where tourism business is expanding.

Koh Chang, Thailand's third largest island, is an island under the administrative region of Trat Province in the eastern part of the Gulf of Thailand with an area of approximately $219.20 \mathrm{~km}^{2}$. The study area is located between 11 degrees latitude 55 minutes to 12 degrees 10 minutes, longitude 102 degrees 10 minutes to 102 degrees 30 minutes (Figure 1). Koh Chang has an important geomorphological feature of the igneous mountain range of the Permo-Triassic volcanic rock era (Englong et al., 2019). Locals call it "Elephant Island" or Koh Chang in Thai (Srinonil et al., 2020). The abundance of natural resources, especially the tropical rainforests and beautiful coastline, has resulted in Koh Chang's enormous tourism potential (Nitivattananon and Srinonil, 2019). Evidence appears since 1982 that tourists traveled to Than Mayom beach, a beach on the east coast of Koh Chang with Than Mayom Waterfall nearby and an important local community, Salak Phet village. During that time, roads were developed to connect Salak Phet village to Bang Bao community as a road along the east coast to the north. During the years 1984-2002, the government has promoted tourism in a more concrete way by issuing a policy to set the national strategy guidelines, issued the 7th National Economic and Social Development Plan (1996), resulting in the construction of hotels and resorts along the narrow coastal plain from Hat Sai Khao beach down to Klong Prao, Kai Bae, and ending at Bang Bao community.

As the area is on the west coast of Koh Chang with tourism potential and a variety of tourism activities, including white sands with soft and fine sand at Hat Sai Khao beach and Khlong Phrao beach, ideal for beach activities and sunset views or trekking in the central part of the island, and snorkeling activities to see corals and marine life on small islands around Koh Chang. With the identity of the recreation area of Koh Chang and in 1996 onwards, a ferry pier was built between Koh Chang and the mainland of Trat, allowing tourists to take their personal cars to travel easily. Koh Chang has obviously changed the land-use from the past, that is, there has been an expansion of buildings to accommodate

\footnotetext{
* Corresponding author
} 
tourists occurring on every beach in the form of hotels, resorts, and various types of services that are fully equipped. Koh Chang has changed more owners from locals to people from other areas. The problems that follow are similar to many other tourist destinations such as Pattaya (Emparanza et al., 2020), Phuket (Nguyen et al., 2021), Koh Samui (Chatkaewnapanon, 2011), etc. As can be seen from the economic development in the coastal areas of the eleven coastal provinces and metropolises in China with coastal reclamation in order to build a large port and support the urbanization and industrialization, causing the environment to deteriorate (Li et al., 2020).

Integrating experiential and institutional perspectives on ecotourism programs should be considered in order to support the expansion of the built-up and recreation expansion in a marine national park. Experiential activities, vessel quantity control, community ecosystem, and financial attributes all aim to engage local communities in tourism, as well as to maintain their communities in harmony with the ecotourism model (Lin et al., 2020). As tourism develops to a certain extent, it clearly affects both physical, social and cultural changes. Such changes are attributed to the readiness of the environment to accommodate, the readiness of local communities to cope with the changing conditions of tourism, entrepreneurial awareness, and environmental tourists, thus resulting in land-use patterns are changing rapidly.

For this reason, geo-informatics technology is needed to be applied in this research to monitor land-use change patterns, especially buildings and recreation areas to understand the pattern and direction of change in such area to find ways to manage land-use as system of regulation, as well as to prevent the expansion of buildings and recreation areas beyond their capacity to affect natural resources and coastal areas in order to maintain sustainable marine tourism in the future. This research aims to study land-use patterns in Koh Chang area, Trat province from 2000-2020 and to study changes in land-use, especially the expansion of buildings and recreation areas during that period using the geo-informatic technique for decisionmaking in determining the direction of spatial management to support the expansion of sustainable tourism in the future.

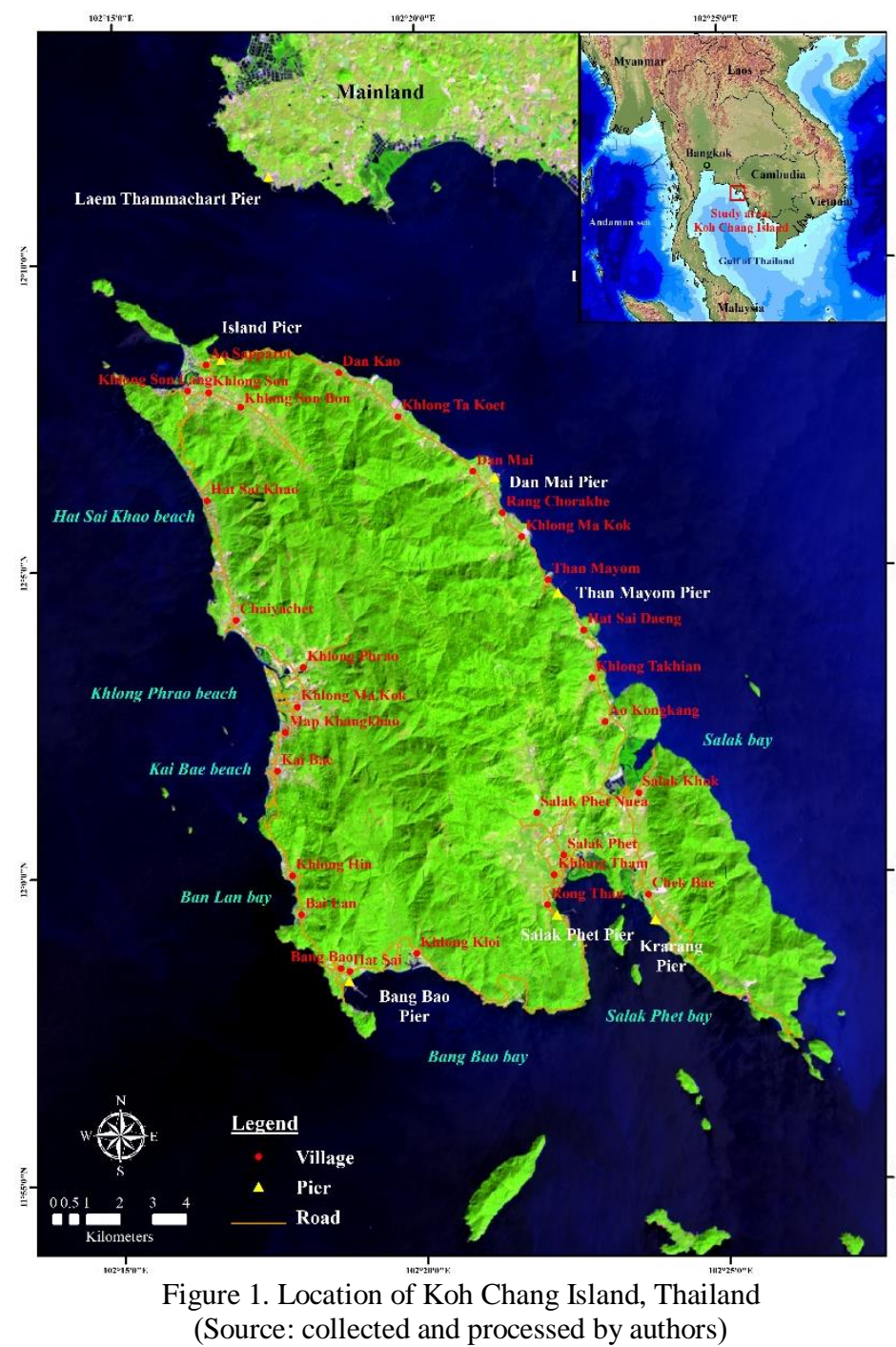

Table 1. Satellite Image Data and Land-use data over the Koh Chang Island for Analysis

\begin{tabular}{|l|c|c|c|}
\hline \multicolumn{1}{|c|}{ Database } & $\begin{array}{c}\text { Acquisition } \\
\text { date }\end{array}$ & Format & Sources \\
\hline $\begin{array}{l}\text { Landsat 5 TM } \\
\text { Satellite Image } \\
\text { Path 128 Row 52 }\end{array}$ & $\begin{array}{c}\text { November } \\
2000\end{array}$ & $\begin{array}{c}\text { Image } \\
\text { File }\end{array}$ & $\begin{array}{c}\text { https://earth } \\
\text { explorer.usgs.gov/ }\end{array}$ \\
\hline $\begin{array}{l}\text { Landsat 7 ETM+ } \\
\text { Satellite Image } \\
\text { Path 128 Row 52 }\end{array}$ & $\begin{array}{c}15 \\
\text { January } \\
2011\end{array}$ & $\begin{array}{c}\text { Image } \\
\text { File }\end{array}$ & $\begin{array}{c}\text { https://earth } \\
\text { explorer.usgs.gov/ }\end{array}$ \\
\hline $\begin{array}{l}\text { Landsat 8 OLI/TIRS } \\
\text { Satellite Image } \\
\text { Path128 Row 52 }\end{array}$ & $\begin{array}{c}12 \\
\text { November } \\
2020\end{array}$ & $\begin{array}{c}\text { Image } \\
\text { File }\end{array}$ & $\begin{array}{c}\text { https://earth } \\
\text { explorer.usgs.gov/ }\end{array}$ \\
\hline $\begin{array}{l}\text { Land-use in Trat } \\
\text { Province 2000 }\end{array}$ & 2000 & $\begin{array}{c}\text { Shape } \\
\text { file }\end{array}$ & $\begin{array}{c}\text { Land Development } \\
\text { Department (LDD), } \\
\text { Thailand }\end{array}$ \\
\hline $\begin{array}{l}\text { Land-use in Trat } \\
\text { Province 2011 }\end{array}$ & 2011 & $\begin{array}{c}\text { Shape } \\
\text { file }\end{array}$ & $\begin{array}{c}\text { Land Development } \\
\text { Department (LDD), } \\
\text { Thailand }\end{array}$ \\
\hline $\begin{array}{l}\text { Land-use in Trat } \\
\text { Province 2020 }\end{array}$ & 2020 & $\begin{array}{c}\text { Shape } \\
\text { file }\end{array}$ & $\begin{array}{c}\text { Land Development } \\
\text { Department (LDD), } \\
\text { Thailand }\end{array}$ \\
\hline
\end{tabular}

\section{MATERIALS AND METHODS}

The study of land-use patterns and land-use change was systematically gathered data, analyzed data and presented research results as follows:

1. Collect spatial data and attribute data from relevant agencies and grant permission to publish as shown Table 1 .

2. Input satellite image data including Landsat-5 (TM system), Landsat-7 (ETM+ system), and Landsat-8 (OLI/TIRS system) in each period, using Erdas Imagine Version 8.5 satellite image data program mixed satellite photo-band, by selecting band 5 (short-wavelength infrared), 4 (near-infrared), and 3 (red) for Landsat TM and ETM+ systems (Abuzar et al., 2020). The Landsat OLI/TIRS system uses band 6 (short-wavelength infrared), 5 (near-infrared), and 4 (red) (Barsi et al., 2014; Li et al., 2014).

3. Interpret satellite image data to classify landuse of 2000, 2011 and 2020 using the satellite image processing program and set the satellite image scale on the image screen to 1:50,000. The key factors in interpretation include shape, arrangement, color, location and surrounding environment. Interpret land-use patterns by Supervised classification (Everitt et al., 2010; Parida and Kumar, 2020). The results from the interpretation of the land-use model are presented as Overall Accuracy and Kappa coefficient coefficient (KHAT) to assess the accuracy of the various data classifications that appear on the satellite image data, by determining 
the sampling point in the study area based on data from Land Development Department (LDD), Thailand

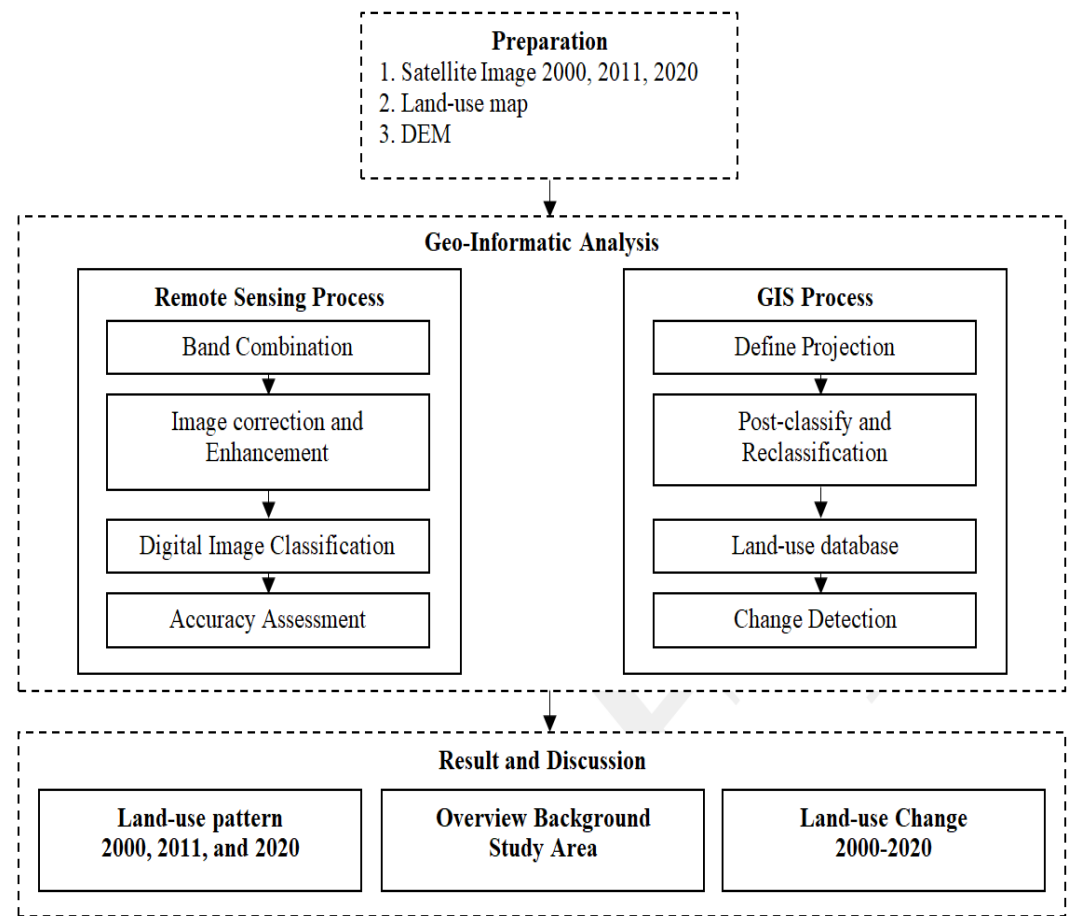

Figure 2. Flowchart of Methodology validation comparison with data obtained from classification. The classification criteria are as follows (Jensen and Kiefer, 2007; Poursanidis et al., 2015):

$<0$ means unacceptable classification data; $0.01-0.40$ means fair classification data; $0.41-0.60$ means moderate classification data;

$0.61-0.80$ means good classification data; $0.81-1.00$ means very good classification data.

4. Use the land-use model data obtained to create a database in the Geographic Information System and check spatial data for errors using a Geographic Information System program, displaying the data to check the land-use change for each time period as the equation 1 (Jia et al., 2014): $\Delta=[(\mathrm{A} 2-\mathrm{A} 1) / \mathrm{A} 1 \times 100] /(\mathrm{T} 2-\mathrm{T} 1)$ where $\Delta$ is the proportion of the change in land-use pattern (percent) time (T1)

A1 is the type of land-use at the first

A2 is the type of land-use at the second time (T2).

The results are shown as the proportion of land-use of each species on the map. It shows the land-use change pattern from 2000 to 2020, along with a comparative table of land-use change detection from the Tabulate area analysis in ArcMap 10.3.

5. Randomly check data from real areas to verify the accuracy of the data obtained from the satellite image data interpretation, i.e., characteristics of land-use, factors and impacts of land-use change, expository inquiries from local people, etc.

6. Use the land-use area model information obtained to create a geographic information database and validate Spatial Data and Attribute Data errors using ArcMap 10.3 geographic information system program to track land-use change and store it as a spatial database for agencies to solve problems and plan appropriate land-use.

\section{RESULTS AND DISCUSSION}

The area of Koh Chang is currently designated as a natural resource conservation area, along with being pushed into a coastal tourist city. The geo-informatic technique has therefore been applied in the study of landuse patterns (Yamashkin et al., 2021; Waiyasusri and Wetchayont, 2020). The satellite image processing by Supervised classification method for each time period in 2000, 2011 and 2020 showed overall accuracy results from the interpretation of the land-use model as shown in Table 2 as follows: $92.60 \%, 77.80 \%$ and $88.00 \%$, respectively. Criteria for classification of land-use data are in good to very good. Kappa coefficient (KHAT) is a coincidence of 2 sets of data from interpretation of land-use patterns with KHAT values as follows: $0.91,0.72$ and 0.85 , respectively, which are also good to very good criteria, and the land-use patterns for each period are shown in Figure

$3 \mathrm{~A}-3 \mathrm{C}$ as shown Table 2. Based on the interpretations of Landsat satellite imagery for all three periods $(2000,2011$, and 2020), the results showed that most of Koh Chang was covered by forest, with an area of $176.75 \mathrm{~km}^{2}(80.63 \%), 176.06$ $\mathrm{km}^{2}(80.23 \%)$, and $170.95 \mathrm{~km}^{2}(77.99 \%)$, respectively. The forest area that appears in the central part of Koh Chang is Deciduous forest and Mangrove forest covering the east and south of the island, following by Cultivated land area 23.61 $\mathrm{km}^{2}(10.77 \%), 24.43 \mathrm{~km}^{2}(11.15 \%)$, and $19.47 \mathrm{~km}^{2}(8.88 \%)$, respectively. Cultivated land covers the surrounding islands of the northern, eastern and southern parts of Koh Chang, mainly Mixed orchard, Coconut, Para rubber, Durian, and Agalloch. The Built-up and Recreation area, a key land-use found to have increased over the 20 years of the study, was $7.22 \mathrm{~km}^{2}(3.29 \%), 7.33 \mathrm{~km}^{2}(3.34 \%)$, and $18.28 . \mathrm{km}^{2}(8.34 \%)$, respectively. It appears densely in the narrow plains surrounding Koh Chang, including the west, north and east of Koh Chang (Figure 3A-3C). The Waterbodies and Other land areas have been relatively stable throughout the past period.

Table 2. Land-use pattern 2000, 2011, and 2020 in Koh Chang Island derived from supervised classification showing Overall accuracy and Kappa coefficient (Source: collected and processed by authors)

\begin{tabular}{|l|c|c|c|c|c|c|}
\hline & \multicolumn{2}{|c|}{$\mathbf{2 0 0 0}$} & \multicolumn{2}{c|}{$\mathbf{2 0 1 1}$} & \multicolumn{2}{c|}{$\mathbf{2 0 2 0}$} \\
\hline Land-use pattern & $\mathbf{k m}^{\mathbf{2}}$ & $\mathbf{\%}$ & $\mathbf{k m}^{\mathbf{2}}$ & $\mathbf{\%}$ & $\mathbf{k m}^{\mathbf{2}}$ & $\mathbf{\%}$ \\
\hline Forest & 176.75 & 80.63 & 176.06 & 80.32 & 170.95 & 77.99 \\
\hline Cultivated land & 23.61 & 10.77 & 24.43 & 11.15 & 19.47 & 8.88 \\
\hline $\begin{array}{l}\text { Built-up and } \\
\text { Recreation area }\end{array}$ & 7.22 & 3.29 & 7.33 & 3.34 & 18.28 & 8.34 \\
\hline Waterbodies & 9.46 & 4.32 & 8.54 & 3.90 & 9.32 & 4.25 \\
\hline Other land & 2.16 & 0.99 & 2.84 & 1.30 & 1.18 & 0.54 \\
\hline Total & 219.20 & 100.00 & 219.20 & 100.00 & 219.20 & 100.00 \\
\hline $\begin{array}{c}\text { Overall Accuracy } \\
\text { (\%) }\end{array}$ & \multicolumn{2}{|c|}{92.60} & \multicolumn{2}{|c|}{77.80} & 88.00 \\
\hline $\begin{array}{c}\text { Kappa coefficient } \\
\text { (KHAT) }\end{array}$ & \multicolumn{2}{|c|}{0.91} & \multicolumn{2}{|c|}{0.72} & \multicolumn{2}{c|}{0.85} \\
\hline
\end{tabular}



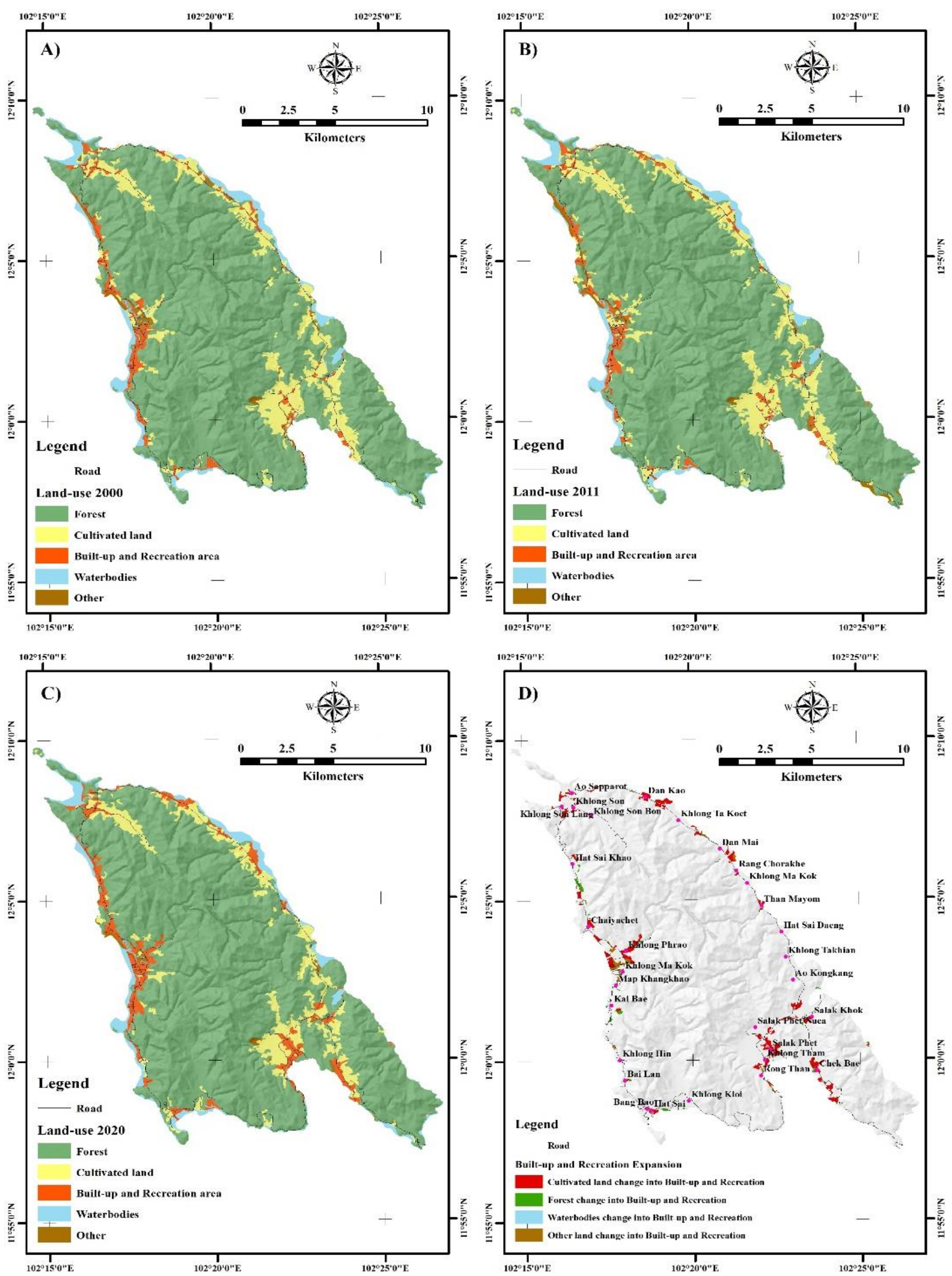

Figure 3. Land-use pattern map in 2000 (A), 2011 (B), and 2020 (C) and Land-use pattern

map in 2000-2020 showing Built-up and recreation expansion (D) (Source: collected and processed by authors)

Geo-informatic technique is an effective analysis of land-use change patterns from 2000-2020 along with a comparison table of land-use change detection from Tabulate area analysis, showing spatial data to show the clarity of the transition of 
the area over time. The results showed that the west, north, and southeast coast of Koh Chang found an expansion of builtup and recreation areas along that coastline (Figure 3D). The results of the study from Table 3 showing the Transition Matrix of land-use changes pattern showed that the area of Koh Chang in the current year 2020, the area with the expansion of the Built-up and Recreation area in 2000 used to be a forest area $7.76 \mathrm{~km}^{2}$; Cultivated land change into Built-up and Recreation area $4.04 \mathrm{~km}^{2}$; and Other land change into Built-up and Recreation area $0.66 \mathrm{~km}^{2}$. It can be seen that Koh Chang has an expansion of Built-up and Recreation area with an increasing trend of $253.19 \%$.

Table 3. Transition Matrix of land-use changes in the Koh Chang Island, 2000-2020 ( $\left.\mathrm{km}^{2}\right)$ (Source: collected and processed by authors)

\begin{tabular}{|c|c|c|c|c|c|c|}
\hline & \multicolumn{6}{|c|}{2020} \\
\hline \multirow{6}{*}{ ఫ్సి } & Land-use & Cultivated land & Forest & Built-up and Recreation area & Waterbodies & Other land \\
\hline & Cultivated land & 16.07 & 3.19 & 4.04 & 0.04 & 0.26 \\
\hline & Forest & 2.36 & 166.60 & 7.76 & 0.02 & 0.01 \\
\hline & Built-up and Recreation area & 0.59 & 0.69 & 5.84 & 0.08 & 0.02 \\
\hline & Waterbodies & 0.14 & 0.28 & 0.00 & 8.93 & 0.13 \\
\hline & Other land & 0.30 & 0.19 & 0.66 & 0.24 & 0.77 \\
\hline
\end{tabular}

Built-up and recreation expansion clearly occurred on the west coast of Koh Chang since Hat Sai Khao village, Chaiyachet village, Khlong Phrao village, Khlong Ma Kok village, Map Khangkhao, and Kai Bae village have expanded their hotels and resorts across the coast due to the white sandy beach with soft and fine sand at Hat Sai Khao beach and Khlong Phrao beach, west of Koh Chang, suitable for beach and sunset activities and development as a tourist attraction to attract both domestic and foreign tourists. The expansion has caused the western coastal area to be crowded with buildings. Some areas extend to the Khlong Phrao stream, which causes the waterway to be blocked and encroached. This affects the drainage system of water masses from the central mountains of the island into the sea. If the Intertropical Convergence Zone crosses over Koh Chang during August-September, it will cause long periods of immersion rain and catastrophic flash floods, which cause sedimentary debris flowing from the mountains to flood the area.

On the other hand, the northern coast of Koh Chang has been replaced by residential buildings, government offices and small resorts. This is because the coastal terrain is not as beautiful as the rocky beaches and lane beaches of the west coast. In addition, some of them are commuter docks and fishing ports. On the southeastern coast of Koh Chang, some of the cultivated areas have been transformed into built-up and recreation areas due to partially cultivated areas in Salak Khok, Salak Phet, Khlong Tham, Rong Than, and Chek Bae communities to support eco-tourism to learn about community lifestyles and conserve coastal resources, especially the mangrove and tropical rainforests of Koh Chang.

The goal of ecotourism is to understand the culture and history of tourist attractions and the way of life of the community, not to alter the abundance of local ecosystems, and to create economic benefits for local communities to get involved in (Crow et al., 2020; Li et al., 2020). Therefore, the areas that should be classified as strict land use requirements in the marine national parks are the east coast (Khlong Phrao village, Khlong Ma Kok village, and Map Khangkhao village) and the west coast of Koh Chang (Salak Khok, Salak Phet, and Khlong Tham village).

The study of land-use changes from 2000-2020 was found to be most susceptible to change, and therefore strategic management for conservation direction orientations along with the development of ecotourism should be undertaken by engaging those communities in action (Palomo et al., 2014). In addition, tourists can also participate in boating activities to see the fishermen's community living together with the forest in a simple atmosphere by "Salak Khok Folk Conservation and Tour Club", which is a gathering of Salak Khok people to conduct ecotourism in conjunction with conservation, and prevent threats from outside venture capitalists conduct business without consideration for natural resources and the environment, including raising awareness of the value of available natural resources, preserving indigenous fisheries lifestyles so that tourism is not a source of income that destroys traditional lifestyles, as the saying goes: "Without tourism, life is alive. With no mangrove forest, no life survives." Another activity that the community does together is Egg Crab Bank, by raising the wild blue crabs that had their eggs outside the shell, after hatching then release the baby crabs back to nature to increase the blue crab population. As a result, the expansion of the built-up and recreation area in the southeast of the island will take the form of eco-tourism development.

\section{CONCLUSION}

Applying geo-informatic technique in tourism can effectively solve the problem of interaction between nature and socio-economic, especially remote sensing. It is a technique that can track changes in the area by using satellites at different times in image processing, allowing useful information to be extracted and analyzed in GIS for solving landuse planning problems. Such spatial data can be used to support decision-making on the monitoring and control of changes in land-use patterns in those areas, along with being a spatial database for effective interaction between local villagers and relevant government agencies in order to manage effective land-use in a concrete manner with clear spatial goals for better future actions in accordance with the principles of the United Nations Sustainable Development Goals (SDGs) and maintain tourist attractions to remain and to be sustainable in the future.

\section{Acknowledgement}

Acknowledgments to the U.S. Geological Survey (Earth Explorer Homepage: https://earthexplorer.usgs.gov/) and Gratefully acknowledge for Suan Sunandha Rajabhat University Research Grant. 


\section{REFERENCES}

Abuzar, M., McAllister, A., Whitfield, D., \& Sheffield, K. (2020). Remotely-Sensed Surface Temperature and Vegetation Status for the Assessment of Decadal Change in the Irrigated Land Cover of North-Central Victoria, Australia. Land, 9(9), 308. https://doi.org/10.3390/land9090308

Barsi, J.A., Lee, K., Kvaran, G., Markham, B.L., \& Pedelty J.A. (2014). The Spectral Response of the Landsat-8 Operational Land Imagery. Remote Sensing, 6(10), 10232-10251. https://doi.org/10.3390/rs61010232

Chatkaewnapanon, Y. (2011). Tourism and History: Change and Adaptation of Locals in the Tourism Period, A Study of Koh Samui in Southern Thailand, Master's Dissertation, University of Otago, Dunedin, New Zealand.

Crow, S.K., Topa, G.T., Nelson, K.D., \& Whitehead, A.L. (2020). Incorporating Māori values into land management decision tools. New Zealand Journal of Marine and Freshwater Research, 54(3), 431-448. https://doi.org/10.1080/00288330.2020.1772322

Dimobe, K., Goetze, D., Ouédraogo, A., Forkuor, G., Wala, K., Porembski, S., \& Thiombiano, A. (2017). Spatio-Temporal Dynamics in Land Use and Habitat Fragmentation within a Protected Area Dedicated to Tourism in a Sudanian Savanna of West Africa. Journal of Landscape Ecology, 10(1), 2017, pp.75-95. https://doi.org/10.1515/jlecol-2017-0011

Emparanza, P.R., Hongkarnjanakul, N., Rouquette, D., Schwob, C., \& Mezeix, L. (2020). Land cover classification in Thailand's Eastern Economic Corridor (EEC) using convolutional neural network on satellite images. Remote Sensing Applications: Society and Environment, 20, 100394. https://doi.org/10.1016/j.rsase.2020.100394

Englong, A., Punwong, P., Selby, K., Marchant, R., Traiperm, P., \& Pumijumnong, N. (2019). Mangrove dynamics and environmental changes on Koh Chang, Thailand during the last millennium. Quaternary International, 500, 128-138. https://doi.org/10.1016/j.quaint.2019.05.011

Everitt, J.H., Yang, C., Judd, F.W., \& Summy, K.R. (2010). Use of archive aerial photography for monitoring black mangrove populations. Journal of Coastal Research, 264, 649-653. https://doi.org/10.2112/jcoastresd-09-00133.1

Gaughan, A.E., Binford, M.W., \& Southworth, J. (2009). Tourism, forest conversion, and land transformations in the Angkor basin, Cambodia. Applied Geography, 29(2), 212-223. https://doi.org/10.1016/j.apgeog.2008.09.007

Gilani, H., Shrestha, H.L., Murthy, M., Phuntso, P., Pradhan, S., Bajracharya, B., \& Shrestha, B. (2015). Decadal land cover change dynamics in Bhutan. Journal of Environmental Management, 148, 91-100. https://doi.org/10.1016/j.jenvman.2014.02.014

Indarto, I., \& Hakim, F.M. (2021). Tracking Land Use Land Cover changes from 2000 to 2018 in a local area of East Java Province, Indonesia. Bulletin of Geography, 52(52), 7-24. http://doi.org/10.2478/bog-2021-0010

Jensen, J.R., \& Kiefer, R.W. (2007). Remote sensing of the environment, Pearson Prentice Hall, New Jersey.

Jia, K., Liang, S., Zhang, L., Wei, X., Yao, Y., \& Xie, X. (2014). Forest cover classification using Landsat ETM+ data and time series MODIS NDVI data. International Journal of Applied Earth Observation and Geoinformation, 33, 32-38, https://doi.org/10.1016/j.jag.2014.04.015

Li, F., Ding, D., Chen, Z., Chen, H., Shen, T., Wu, Q., \& Zhang, C. (2020). Change of sea reclamation and the sea-use management policy system in China. Marine Policy, 115, 103861. https://doi.org/10.1016/j.marpol.2020.103861

Li, P., Jiang, L., \& Feng, Z. (2014). Cross-Comparison of Vegetation Indices Derived from Landsat-7 Enhanced Thematic Mapper Plus (ETM+) and Landsat-8 Operational Land Imager (OLI) Sensors. Remote Sensing, 6(1), 310-329. https://doi.org/10.3390/rs6010310

Lin, Y., Hong, C., Lee, C., \& Chou, Y. (2020). Integrating multiple perspectives into an ecotourism marketing strategy in a Marine National Park. Asia Pacific Journal of Tourism Research, 25(9), 948-966, https://doi.org/10.1080/10941665.2020.1805474

Nguyen, H.A.T., Sophea, T., Gheewala, S.H., Rattanakom, R., Areerob, T., \& Prueksakorn, K. (2021). Integrating remote sensing and machine learning into environmental monitoring and assessment of land use change. Sustainable Production and Consumption, 27, 1239-1254. https://doi.org/10.1016/j.spc.2021.02.025

Nitivattananon, V., \& Srinonil, S. (2019). Enhancing coastal areas governance for sustainable tourism in the context of urbanization and climate change in eastern Thailand. Advances in Climate Change Research, 10, 47-58. https://doi.org/10.1016/j.accre.2019.03.003

Osman, T., Arima, T., \& Divigalpitiya, P. (2016). Measuring Urban Sprawl Patterns in Greater Cairo Metro-politan Region. Journal of the Indian Society of Remote Sensing, 44(2), 287-295. https://doi.org/10.1007/s12524-015-0489-6

Palomo, I., Martín-López, B., Zorrilla-Miras, P., Amo, D.G.D., \& Montes, C. (2014). Deliberative mapping of ecosystem services within and around Doñana National Park (SW Spain) in relation to land use change. Regional Environmental Change, 14, $237-251$. https://doi.org/10.1007/s10113-013-0488-5

Parida, B.R., \& Kumar, P. (2020). Mapping and dynamic analysis of mangrove forest during 2009-2019 using landsat-5 and sentinel-2 satellite data along Odisha Coast. Tropical Ecology, 61, 538-549. https://doi.org/10.1007/s42965-020-00112-7

Poursanidis, D., Chrysoulakis, N., \& Mitraka, Z. (2015). Landsat 8 vs. Landsat 5: A comparison based on urban and peri-urban land cover mapping, International Journal of Applied Earth Observation and Geoinformation, 35, 259-269, https://doi.org/10.1016/j.jag.2014.09.010

Srinonil, S., Nittivattananon, V., Noithammaraj, P., \& Nitisoravut, R. (2020). Tourism Governance for Coastal Urbanization and Environment with Changing Climate on Koh Chang Island, Thailand. GMSARN International Journal, 14, $82-88$.

Waiyasusri, K., \& Wetchayont, P. (2020). Assessing Long-Term Deforestation In Nam San Watershed, Loei Province, Thailand Using A Dyna-Clue Model. Geography, Environment, Sustainability, 13(4), 81-97. https://doi.org/10.24057/2071-9388-2020-14

Yamashkin, A.A., Yamashkin, S.A., Radovanovich, M.M., Moskaleva, S.A., \& Zarubin, O.A. (2021). Geoinformation Support of Tourist and Recreation Development of Cultural Landscape of the Republic of Mordovia (Russia). GeoJournal of Tourism and Geosites, 37(3), 873-879. https://doi.org/10.30892/gtg.37318-720

*** Government of Thailand. (1996). The Seventh National Economic and Social Development Plan (1992-1996). The National Economic and Social Development Board, Office of The Prime Minister of Thailand.

Article history: Received: 11.07.2021 Revised: 14.12.2021 Accepted: 21.12.2021 Available online: 31.12 .2021 